\title{
IDENTIFICATION AND QUANTIFICATION OF PHENOLIC COMPOUNDS IN POMEGRANATE JUICES FROM EIGHT MACEDONIAN CULTIVARS
}

\author{
Jasmina Petreska Stanoeva ${ }^{1, *}$, Nina Peneva ${ }^{1}$, Marina Stefova ${ }^{1}$, Viktor Gjamovski ${ }^{2}$ \\ ${ }^{1}$ Institute of Chemistry, Faculty of Natural Sciences and Mathematics, Ss Cyril and Methodius University, \\ Skopje, Republic of Macedonia \\ ${ }^{2}$ Institute of Agriculture, Ss Cyril and Methodius University, Skopje, Republic of Macedonia
}

jasmina.petreska@pmf.ukim.mk

Punica granatum $\mathrm{L}$. is one of the species enjoying growing interest due to its complex and unique chemical composition that encompasses the presence of anthocyanins, ellagic acid and ellagitannins, gallic acid and gallotannins, proanthocyanidins, flavanols and lignans. This combination is deemed responsible for a wide range of health-promoting biological activities.

This study was focused on the analysis of flavonoids, anthocyanins and phenolic acids in eight pomegranate varieties (Punica granatum) from Macedonia, in two consecutive years. Fruits from each cultivar were washed and manually peeled, and the juice was filtered. $\mathrm{NaF}(8.5 \mathrm{mg})$ was added to $100 \mathrm{ml}$ juice as a stabilizer. The samples were centrifuged for $15 \mathrm{~min}$ at $3000 \mathrm{rpm}$ and analyzed using an $\mathrm{HPLC} / \mathrm{DAD} / \mathrm{MS}^{\mathrm{n}}$ method that was optimized for determination of their polyphenolic fingerprints.

The dominant anthocyanin in all pomegranate varieties was cyanidin-3-glucoside followed by cyanidin and delphinidin 3,5-diglucoside. From the results, it can be concluded that the content of anthocyanins was higher in 2016 compared to 2017. But in contrast, the total content of non-colored polyphenols was around 10 times lower in 2016 compared to the amount found in the same samples in 2017.

Keywords: pomegranate; polyphenols; HPLC/MS

\section{ИДЕНТИФИКАЦИЈА И КВАНТИФИКАЦИЈА НА ФЕНОЛНИ СОЕДИНЕНИЈА ВО СОКОТ НА ОСУМ МАКЕДОНСКИ СОРТИ КАЛИНКИ}

Punica granatum L. е еден од видовите што предизвикуваат голем интерес поради својот комплексен и уникатен хемиски состав кој опфаќа присуство на антоцијани, елагова киселина и елагитанини, гална киселина и галотанини, проантоцијанидини, флаваноли и лигнани. Оваа комбинација од соединенија се смета одговорна за широк спектар биолошки процеси поврзани со здравјето.

Истржувањето беше фокусирано на анализа на флавоноиди, антоцијани и фенолна киселина во осум сорти калинки (Punica granatum) од Македонија, од две последователни години. Зрната од овошјето беа измиени и рачно сепарирани од остатокот и сокот беше добиен со филтрирање. Кон секој примерок беше додадено 8,5 mg NaF на $100 \mathrm{ml}$ сок како стабилизатор. Примероците беа центрифугирани во временски интервал од 15 минути на 3000 вртежи во минута и беа анализирани со употреба на $\mathrm{HPLC} / \mathrm{DAD} / \mathrm{MS}^{\mathrm{n}}$ и овој метод беше оптимизиран за одредување на полифенолните маркери.

Доминантен антоцијанин кај сите сорти калинки беше цијанидин-3-глукозид, проследен со цијанидин и делфинидин 3,5-диглукозид. Од резултатите, може да се заклучи дека содржината на антоцијанини била повисока во 2016 година во однос на 2017 година. Но, спротивно на тоа, вкупната содржина на безбојните полифеноли беше околу 10 пати помала во 2016 година, во споредба со количината пронајдена во исти примероци во 2017 година. 


\section{INTRODUCTION}

In recent years, there has been a growing interest in the consumption of healthy and functional foods due to their demonstrated health benefits. Epidemiological studies suggest that regular consumption of fruits reduces the risk of chronic and degenerative human diseases [1], and many of the health benefits have been attributed to the presence of polyphenolic compounds [2]. Fresh fruits and products thereof (e.g., fruit juices, fruit teas and jams) are valuable sources of polyphenols. Polyphenolic compounds form a large group of substances that differ in the number of aromatic rings, their linkage, and the presence of functional groups (e.g., hydroxylation and/or methoxylation) on the rings. Several hundred polyphenols have already been identified in plant-derived foods. Polyphenols are secondary metabolites. They are most frequently bound to sugar moieties, and therefore they are water soluble. According to their chemical struc- ture, they can be divided into several groups (Fig. 1) including phenolic acids and flavonoids [3]. Polyphenolic substances show antioxidant activity by reacting as reducing substances, proton donors, and scavengers of free radicals, and by forming chelates with metal cations. In addition to their protective role against oxidative damage, polyphenols have been reported to exhibit antiinflammatory, antiallergic, antiviral and vasodilator activities in humans [4].

Nowadays, Punica granatum L. is one of those species enjoying growing interest after a period of being an out-fashioned fruit with limited commercial appeal, mostly due to the time and patience needed to remove the rind and the tiny seeds. In particular, the juice obtained from pomegranates is experiencing a soaring success in the marketplace. This has been spurred by several features including a favorable combination of novelty, price, availability, color, unique taste, and health properties $[5,6]$.

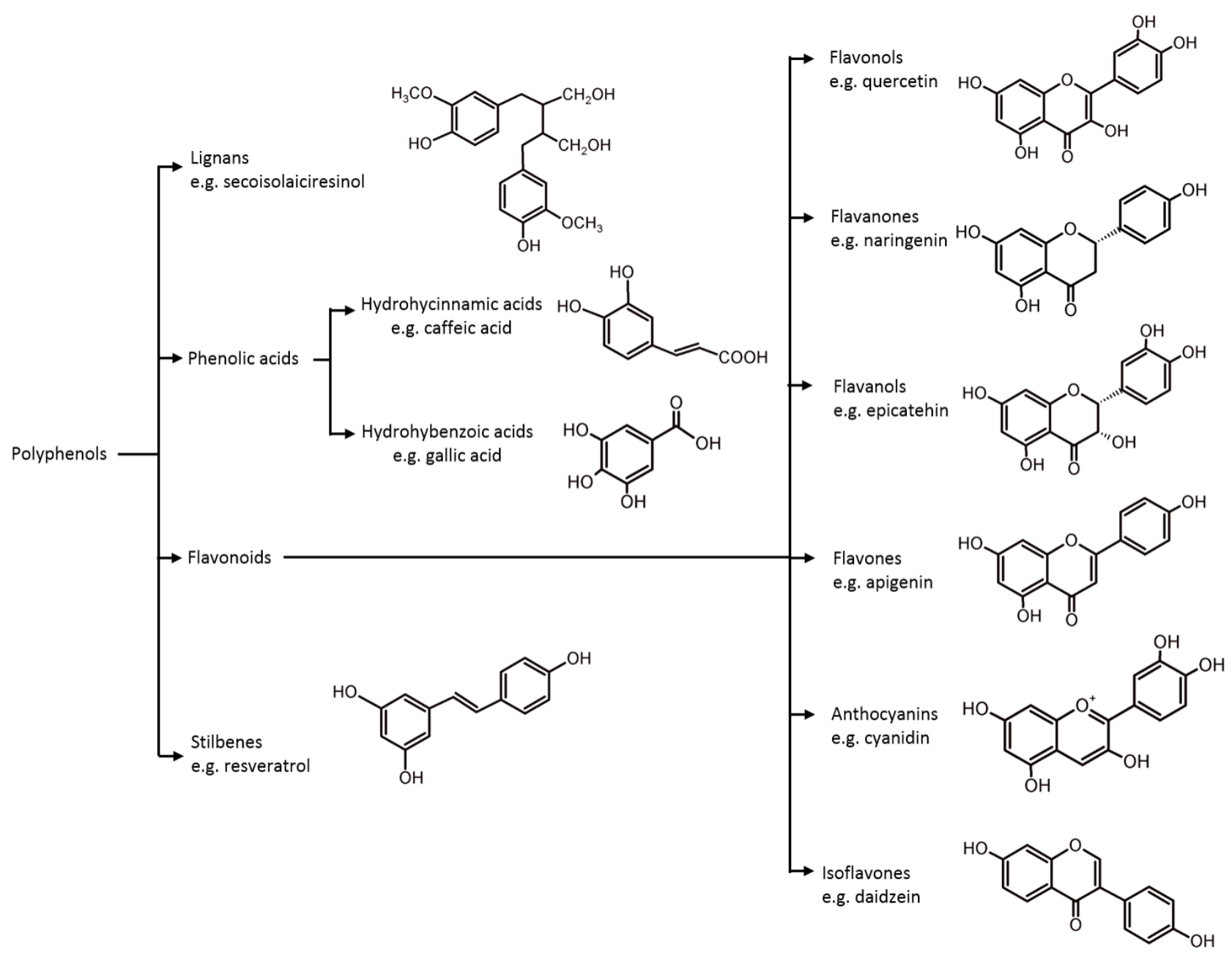

Fig. 1. Chemical structures of the main classes of polyphenols 
The latter are strictly related to the phytochemical composition of this fruit, which is both complex and unique and encompasses the presence of anthocyanins (monoglycosides and diglycosides of cyanidin, delphinidin, and pelargonidin), ellagic acid and ellagitannins (mainly punicalagins and punicalins), gallic acid and gallotannins, proanthocyanidins, flavanols and lignans, whose combination is deemed responsible for a wide range of health-promoting biological activities exerted both directly or after an assimilation mediated through colonic biotransformation [7-10].

The aim of this work was to study the complex polyphenolic composition of eight pomegranate varieties (Punica granatum) from Macedonia, collected in two consecutive years, including both anthocyanin and non-anthocyanin compounds. For this purpose, a method using high-performance liquid chromatography with diode array detection and tandem mass spectrometry with positive and negative electrospray ionization (HPLC-DAD$\mathrm{ESI} / \mathrm{MS}^{\mathrm{n}}$ ) with an ion-trap mass analyzer was developed and optimized. The obtained results give an insight into the polyphenolic profile of the pomegranate fruits from the Balkan climate.

\section{MATERIALS AND METHODS}

\subsection{Reagents and chemicals}

Formic acid, methanol and water were purchased from Merck (Darmstadt, Germany). A standard of malvidin-3-glucoside chloride was purchased from Phytolab (Vestenbergsgreuth, Germany); (-)-epicatechin, gallic acid, ellagic acid, and quercetin were from Sigma (Darmstadt, Germany); caffeic acid was from Genay (Lyon, France).

\subsection{Plant material}

Eight autochthonic pomegranate cultivars (Zumnarija, Hidzas, Kisela, Bernarija, Limfonka, Ropkavac, Karamustafa, Valandovka) were selected from mature fruits grown in Valandovo, south part of Macedonia, in two consecutive years (2016, 2017). Ten kilograms of each cultivar were picked at maturity. According to Mirdehghan and Rahemi (2007) [11], the harvest maturity for pomegranate is achieved in September, when the arils' weight is greater than that of the peel. Fruits were transferred to a $4{ }^{\circ} \mathrm{C}$ storeroom on the same day as they were harvested. To avoid possible contamination of the juices with the metabolites produced by microorganisms, fruits with cracks, cuts, sunburn, and oth- er defects in the husk were disposed of. During the experiments, only healthy fruits of uniform size and appearance were arranged in one row in wooden boxes containing packing material.

\subsection{Sample preparation}

Fruits for each cultivar were manually peeled, and juice was obtained from pomegranate arils by a hand press. The juice passed through a perforated plate and the seeds and pulp remained on the plate. Solid NaF $(8.5 \mathrm{mg}$ ) was added to 100 $\mathrm{ml}$ juice (corresponding to $2 \mathrm{mM}$ ) to inactivate polyphenol oxidases and prevent phenolic degradation [12]), then the samples were centrifuged for $15 \mathrm{~min}$ at $3000 \mathrm{rpm}$ at room temperature. The supernatant was filtered through a $0.45 \mu \mathrm{m}$ nylon membrane before analysis using an HPLC/DAD/MS ${ }^{\mathrm{n}}$ method that was optimized for determination of their polyphenolic fingerprints.

\section{4. $L C / D A D / E S I-M S^{n}$ analysis}

Chromatographic separations were carried out on a $250 \mathrm{~mm} \times 4.6 \mathrm{~mm}, 5 \mu \mathrm{m}$, Supelco C18 Discovery column (Sigma-Aldrich, Germany). The mobile phase consisted of water-formic acid ( $2 \%$, v/v) (A) and methanol (B). Gradient elution method was used (0-5 min, $5 \% \mathrm{~B}$; 5-20 min, 5-35\% B; 20-45 min, 35-50\% B; 45-55 min, 50-70 \% B; 55-60 min, 70-100 \% B and 60-65 min, $15 \% \mathrm{~B}$ ). The flow rate used was $0.35 \mathrm{ml} / \mathrm{min}$. The injection volume was $10 \mu 1$.

The HPLC system was equipped with an Agilent 1100 series diode array detector and an ion trap mass detector in series (Agilent Technologies, Waldbronn, Germany). It consisted of a G1312A binary pump, a G1329A autosampler, a G1379B degasser and a G1315D photodiode array detector; it was controlled by ChemStation software (Agilent, v.08.03). Spectral data from all peaks were accumulated in the range $190-600 \mathrm{~nm}$ and chromatograms were recorded at $260 \mathrm{~nm}$ for hydrolysable tannins and gallocatehins, at $280 \mathrm{~nm}$ for hydroxybenzoic acids, at $320 \mathrm{~nm}$ for hydroxycinnamic acids, at $350 \mathrm{~nm}$ for flavonols, and at $520 \mathrm{~nm}$ for anthocyanins.

The mass detector was a G2449A ion-trap mass spectrometer equipped with an electrospray ionization (ESI) system and controlled by LCMSD software (Agilent, v.6.1.). Nitrogen was used as the nebulizing gas at a pressure of $50 \mathrm{psi}$, and the flow was adjusted to $12 \mathrm{l} / \mathrm{min}$. The heated capillary and the voltage were maintained at $325^{\circ} \mathrm{C}$ and $4 \mathrm{kV}$, respectively. The parameters for capillary exit off- 
set, skimmer 1, and skimmer 2 were $100 \mathrm{~V}, 40 \mathrm{~V}$ and $6 \mathrm{~V}$, respectively, and compound stability was $100 \%$. MS data were acquired in the positive and negative ionization modes. The full scan covered the mass range at $m / z, 50-1200$.

\subsection{Identification and quantification of polyphenolic compounds}

Liquid chromatography with diode-array detection (LC-DAD) was used for separation and quantification. Peak assignment of the various classes of polyphenols in the chromatograms was based on the comparison of their retention behavior and UV-Vis spectra to those of the authentic compounds and literature data. The conjugated forms of polyphenolic compounds were further characterized by electrospray ionization mass spectrometric detection in the positive ionization mode for anthocyanins and in the negative ionization mode for the other non-colored compounds.

Quantification was performed directly by HPLC/DAD using five-point regression curves $\left(\mathrm{R}^{2}\right.$ $\geq 0.999$ ) of authentic standards. Anthocyanins were quantified with cyanidin 3-O-glucoside chloride at $520 \mathrm{~nm}$, flavonols were determined at 350 $\mathrm{nm}$ as quercetin equivalent, hydroxycinnamic acids were determined at $320 \mathrm{~nm}$ using caffeic acid as external standard, hydroxybenzoic acids were determined at $280 \mathrm{~nm}$ using gallic acid; hydrolysable tannins at $260 \mathrm{~nm}$ as ellagic acid, and gallocatehins at $260 \mathrm{~nm}$ as (-)-epicatechin.

In case of overlapping peaks in the DADchromatograms, separate quantitation was possible with the help of the extracted ion chromatograms (EICs) at the $m / z$ values of the corresponding molecular ions of each overlapping compound: the EIC integral value was used to estimate the contribution of each individual overlapping compound to the joint DAD peaks. Total content is the sum of the contents of all individual phenolic compounds.

\section{RESULTS AND DISCUSSION}

\subsection{Characterization of phenolic compounds by $H P L C / D A D / M S^{n}$}

In total, 26 different polyphenolic compounds were detected in all studied samples and they were classified into the following groups: anthocyanins, hydrolysable tannins (gallotannins and ellagitannins), phenolic acids (hydroxybenzoic and hydroxycinnamic acids), flavan 3-ols and flavonols. The retention times, UV/Vis, and mass spectral characteristics as well as peak assignments for all compounds are specified in Table 1. The HPLC-DAD chromatograms are presented in Figure 2 (peak assignments as in Table 1).

Eight different anthocyanins were found in all analyzed samples. The anthocyanins revealed the typical UV and MS behavior in ESI (+)experiments. From the UV and MS data, three anthocyanidins were detected. The $\left[\mathrm{Y}_{0}\right]^{+}$ions at $\mathrm{m} / z$ 303, 287, and 271 indicated delphinidin (aglycone of compounds A1 and A4), cyanidin (A2, A5, A7 and A8), and pelargonidin (A3 and A6) (Fig. 3a). They also showed sequential loss of their sugar moieties, releasing the three aglycones in $\mathrm{MS}^{2}$ experiments.

All anthocyanins were found in all analyzed samples in the two consecutive years except for cyanidin 3,5-pentoside-hexoside (A5), which was found only in 2016 in the samples from Bejnarija and Valandovka.

Eighteen different polyphenols belonging to six subclasses of non-colored polyphenols (gallotannins, ellagitannins, hydroxybenzoic and hydroxycinnamic acids, flavan-3-ols and flavonols) were tentatively identified.

As already reported in the literature $[4,13$, 14], hydrolyzable tannins are the most abundant polyphenolic compounds in pomegranate juice and include gallotanins, ellagitannins and gallagyl esters such as punicalagin and punicalin.

The detected gallotannin showed a UV spectrum that is similar to that of gallic acid $\left(\lambda_{\max }=269\right.$ $\mathrm{nm})$. Galloyl hexose (T1) revealed an $[\mathrm{M}-\mathrm{H}]^{-}$ion at $\mathrm{m} / z, 331$ and produced a fragment ion at $\mathrm{m} / z, 169$ $\left(\mathrm{MS}^{2}\right)$, indicating the loss of a hexose moiety and base ion characteristic for gallic acid.

Ellagic acid (T8) (Fig. 3b) was previously found in pomegranate samples $[8,15,16]$. It exhibited UV maxima at 254 and $368 \mathrm{~nm}$, a deprotonated molecular ion at $\mathrm{m} / \mathrm{z}, 301$, and fragment ions produced in $\mathrm{MS}^{2}$ at $\mathrm{m} / \mathrm{z} 257$ and 229.

Three compounds (T5, T6 and T7) with $[\mathrm{M}-\mathrm{H}]^{-}$at $\mathrm{m} / \mathrm{z}, 433,447$, and 463 were detected. In $\mathrm{MS}^{2}$ all three produced fragment ions at $\mathrm{m} / \mathrm{z}, 301$ indicating the presence of an ellagic acid moiety. The loss of 132, 146, and 162 indicated the presence of a pentose, rhamnose and hexose unit, respectively. Hence, these compounds were identified as ellagic acid pentoside, ellagic acid rhamnoside and ellagic acid hexoside, respectively. 
Table 1

Retention times, UV/Vis spectra and characteristic ions of polyphenolic compounds of pomegranate

\begin{tabular}{|c|c|c|c|c|c|}
\hline Peak no. & Compound & $t_{\mathrm{R}} / \mathrm{min}$ & $\lambda_{\max } / \mathrm{nm}$ & {$[\mathrm{M}]^{+} /[\mathrm{M}-\mathrm{H}]^{-}$} & $\mathrm{MS}^{2}$ \\
\hline & Anthocyanins & & & & \\
\hline $\mathbf{A 1}$ & delphinidin-3,5-diglucoside & 25.0 & $272,300,524$ & $627^{+}$ & 465,303 \\
\hline A2 & cyanidin-3,5-diglucoside & 29.9 & $240,276,516$ & $611^{+}$ & 449,287 \\
\hline $\mathbf{A 3}$ & pelargonidin-3,5-diglucoside & 34.2 & 276,504 & $595^{+}$ & 433,271 \\
\hline A4 & delphinidin-3-glucoside & 35.8 & $240,278,528$ & $465^{+}$ & 447,303 \\
\hline A5 & cyanidin 3,5-pentoside-hexoside & 37.5 & 278,518 & $581^{+}$ & 287 \\
\hline A6 & cyanidin-3-glucoside & 41.1 & $240,280,520$ & $449^{+}$ & 287 \\
\hline A7 & pelargonidin-3-glucoside & 45.4 & 276,504 & $433^{+}$ & 271 \\
\hline \multirow[t]{3}{*}{ A8 } & cyanidin-3-pentoside & 51.9 & 282,520 & $419^{+}$ & 287 \\
\hline & Hydrolysable tannins & & & & \\
\hline & $\underline{\text { Gallotannins }}$ & & & & \\
\hline \multirow[t]{2}{*}{ T1 } & galloyl hexoside & 17.9 & 266,375 & 331 & 271,169 \\
\hline & $\underline{\text { Ellagitannins }}$ & & & & \\
\hline $\mathbf{T} 2$ & lagerstannin C (galloyl HHDP glucose) & 26.5 & 260 & 649 & 497,301 \\
\hline T3 & pedunculagin I (bis-HHDP glucose) & 30.5 & 256,380 & 783 & 601,301 \\
\hline T4 & Punicalin & 33.9 & 260,380 & 781 & $721,601,301$ \\
\hline T5 & ellagic acid pentoside & 44.8 & 254,366 & 433 & 301 \\
\hline T6 & ellagic acid rhamnoside & 46.7 & 254,360 & 447 & 301,257 \\
\hline T7 & ellagic acid hexoside & 47.1 & 254,360 & 463 & 301 \\
\hline \multirow[t]{3}{*}{ T8 } & ellagic acid & 49.0 & 254,368 & 301 & 257 \\
\hline & Phenolic acids & & & & \\
\hline & $\underline{\text { Hydroxycinnamic acids }}$ & & & & \\
\hline Ac1 & caffeic acid hexoside & 15.0 & 332 & 341 & $179,161,135$ \\
\hline Ac2 & 5-O-caffeoylquinic acid & 21.8 & 316,325 & 353 & $191,163,145$ \\
\hline Ac3 & feruloylquinic acid & 27.0 & 290,326 & 367 & $191,179,144$ \\
\hline Ac4 & ferulic acid hexoside & 35.2 & 280,332 & 355 & 217,193 \\
\hline \multirow[t]{2}{*}{ Ac5 } & caffeic acid & 36.5 & 290,328 & 179 & 143,119 \\
\hline & $\underline{\text { Hydroxybenzoic acids }}$ & & & & \\
\hline Ac6 & gallic acid & 24.3 & 270 & 169 & 125 \\
\hline \multirow[t]{3}{*}{ Ac7 } & vanillic acid hexoside & 37.3 & 254,298 & 329 & 167 \\
\hline & Flavonoids & & & & \\
\hline & Flavan 3-ols & & & & \\
\hline \multirow[t]{2}{*}{ F1 } & gallocatehin & 36.0 & 264 & 305 & 219,179 \\
\hline & $\underline{\text { Flavonols }}$ & & & & \\
\hline F2 & kaempferol hexoside & 40.1 & 284,340 & 447 & 285 \\
\hline F3 & quercetin & 42.6 & 252,360 & 301 & 163 \\
\hline
\end{tabular}




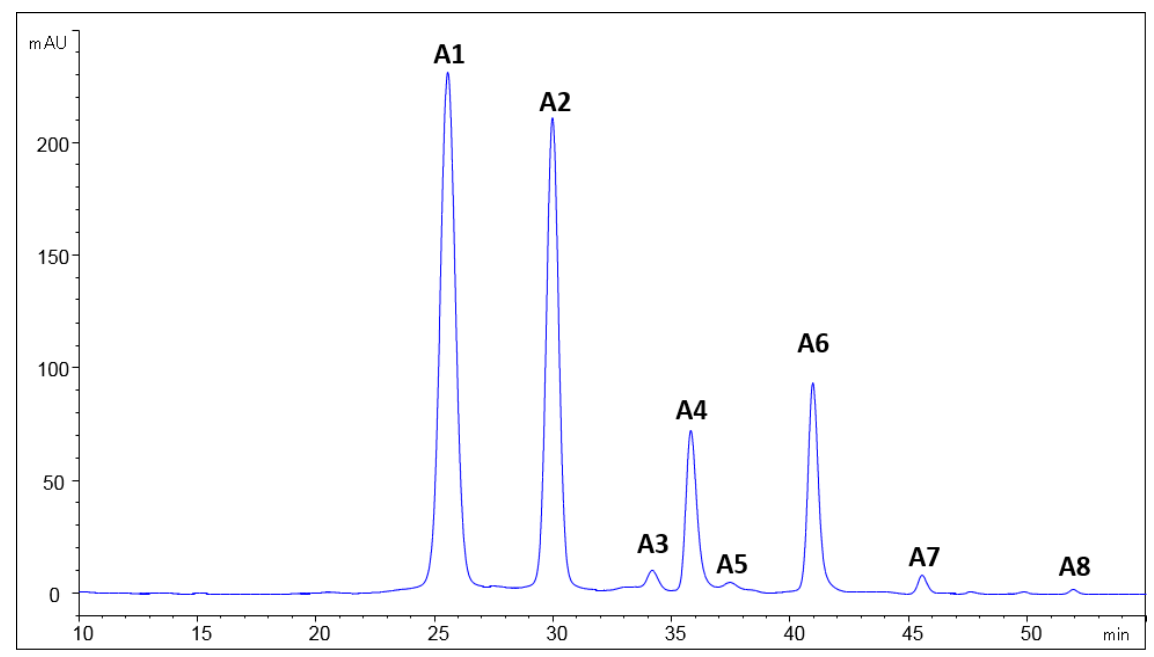

(a)

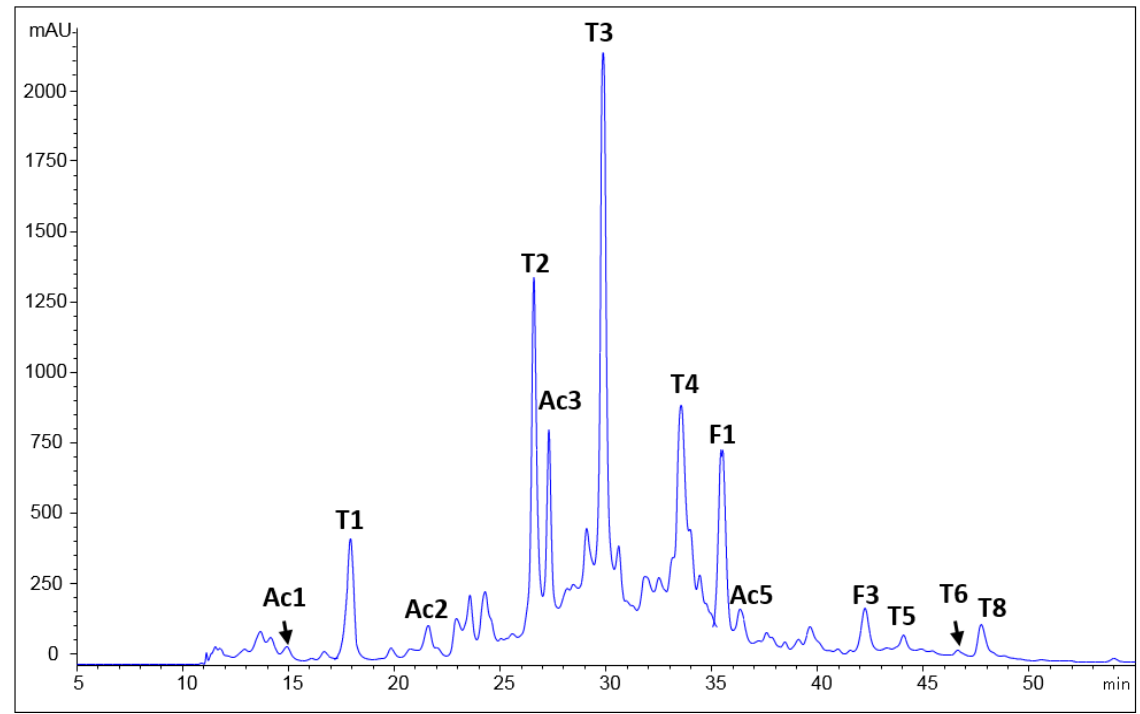

(b)

Fig. 2. HPLC-DAD chromatograms of pomegranate: (a) $520 \mathrm{~nm}$, cultivar Valandovska, 2016, (b) $280 \mathrm{~nm}$, cultivar Zumnarija, 2017

Due to their ability to yield urolithins after metabolism within the digestive tract, ellagitannins (polymeric structures including but not limited to different numbers of galloyl and hexahydroxydiphenoyl (HHDP) units esterified with glucose) are supposed to be the main bioactive phytochemicals of pomegranate juice. Seven ellagitannins were detected in the pomegranate juices assessed. They were distinguished by their characteristic fragment ion spectra yielding sequential losses of galloyl $(\mathrm{m} / \mathrm{z} 152)$, gallate $(\mathrm{m} / \mathrm{z}, 170)$, and HHDP residues $(\mathrm{m} / \mathrm{z} 301)$.

Compound T3 exhibited an $[\mathrm{M}-\mathrm{H}]^{-}$ion at $\mathrm{m} / \mathrm{z} 783$ and fragment ions in the $\mathrm{MS}^{2}$ experiment at $\mathrm{m} / \mathrm{z} 601$ (gallagic acid) and $\mathrm{m} / \mathrm{z} 301$ (ellagic acid). Based on this fragmentation, compound $\mathbf{T 3}$ was identified as bis-HHDP-hexoside (pedunculagin I, Fig. 3c). Compound T3 occurred in three isomeric forms as can be deduced from the reten- tion times (if any are present), and the isomers also differed in their fragmentation pathways as has been previously reported $[17,18]$.

An ellagitannin with a gluconic acid core was also found in pomegranates. Compound T2 was identified as galloyl-HHDP-gluconic acid (lagerstannin C, Fig. 3d). Its $[\mathrm{M}-\mathrm{H}]^{-}$ion at $\mathrm{m} / \mathrm{z} 649$ released fragments at $\mathrm{m} / \mathrm{z}, 497$ and 301 resulting from the loss of gallic acid (releasing HHDP gluconic acid) and ellagic acid, respectively. This compound has been previously found in pomegranate samples collected in Italy [14].

Compound T4 was identified as punicalin (4,6-gallagyl-glucoside) (Fig. 3e) which revealed the loss of gallagic acid $(\mathrm{m} / \mathrm{z}$ 601) and ellagic acid $(\mathrm{m} / \mathrm{z}, 301)$ moieties in the $\mathrm{MS}^{2}$ experiment. It has also been identified in pomegranate samples collected from Italy and California [14, 15]. 


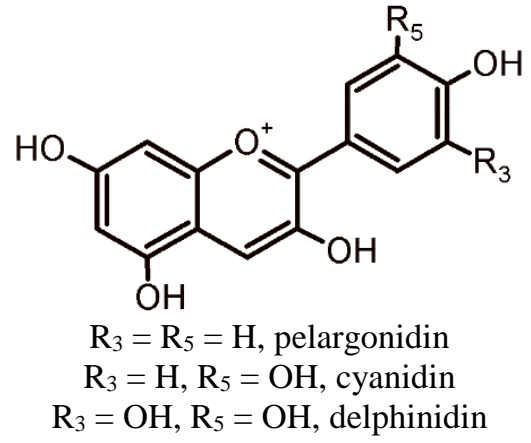

(a)

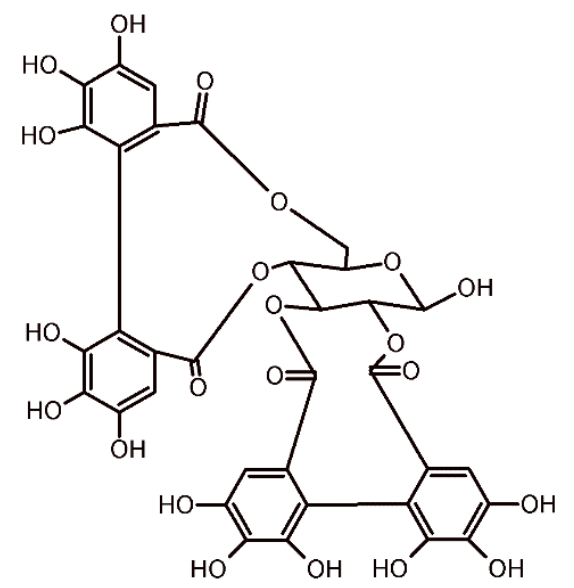

(c)

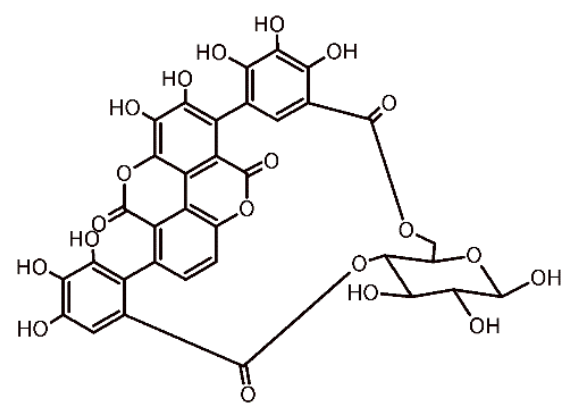

(e)<smiles>[R]OC(=O)C(C)C(=O)OC[R]([R])=O</smiles>

$(\mathrm{g})$<smiles>O=c1oc2c(O)c(O)cc3c(=O)oc4c(O)c(O)cc1c4c23</smiles>

(b)<smiles>O=C(OC1C(O)C(O)C(C(O)C(=O)O)C1OC(=O)c1cc(O)c(O)c(O)c1-c1c(C(=O)O)cc(O)c(O)c1O)c1cc(O)c(O)c(O)c1</smiles>

(d)<smiles>O=C(O)[C@]1(O)C[C@@H](O)[C@H](O)C[C@H]1O</smiles>

(f)

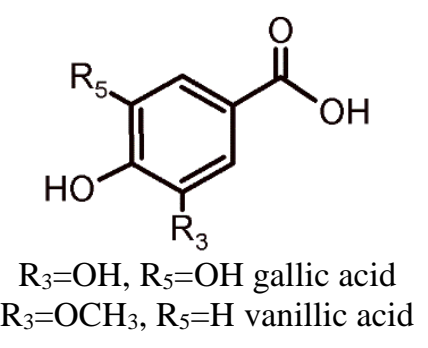

(h)

Fig. 3. Chemical structures of (a) anthocyanidins, (b) ellagic acid, (c) pedunculagin I, (d) lagerstannin C, (e) punicalin, (f) quinic acid, (g) hydroxycinnamic acids, (h) hydroxybenzoic acids

Among hydroxycinnamic acids, compound Ac1 was identified as caffeic acid hexoside $(\mathrm{m} / \mathrm{z}$ 341 ), which showed a loss of a hexose moiety in the $\mathrm{MS}^{2}$ experiment (162) and a partial decarboxy- lation of the caffeic acid moiety resulting in fragments at $\mathrm{m} / \mathrm{z} 179$ and 135, whereas compound Ac4 was identified as ferulic acid hexoside after loss of 162 resulting in a fragment at $\mathrm{m} / \mathrm{z} 193$. 
Furthermore, a compound with an $[\mathrm{M}-\mathrm{H}]^{-}$ ion at $\mathrm{m} / z 353$ (Ac2) was detected and identified as chlorogenic acid (5- $O$-caffeoylquinic acid) by comparison of its retention time, UV and mass spectra with those of an authentic reference substance. Similarly, compound $\mathbf{A c 5}(\mathrm{m} / \mathrm{z}, 179)$ was identified as caffeic acid, whereas Ac3, with $[\mathrm{M}-\mathrm{H}]^{-}$at $\mathrm{m} / z 367$ and fragment ion at $\mathrm{m} / \mathrm{z} 191$ (quinic acid moiety), was identified as a feruloylquinic acid isomer.

Only two hydroxybenzoic acids were detected, gallic acid (at $\mathrm{m} / \mathrm{z}=169)$ (Ac6) and vanillic acid hexoside (at $m / z=329)$ (Ac7).

From the group of flavonoids, only one flavan-3-ol was detected with an absorption maximum at $264 \mathrm{~nm}$, a deprotonated molecular ion at $m / z 305$ and fragment ions in $\mathrm{MS}^{2}$ at $m / z, 219,179$. This compound was identified as gallocatehin (F1). The last two compounds belong to the group of flavonols, and according to their UV and MS spectra they were identified as kaempferol hexoside (F2) and quercetin (F3).

\subsection{Quantification of phenolic compounds by $H P L C / D A D$}

All results for the content of every measured compound in all studied cultivars from two seasons of pomegranate samples are given in Table 2 . The total phenolic content (TPC) of the eight pomegranate cultivars analyzed in the two years is given in the graph in Figure 4, where the polyphenolic patterns are given as distributed in the groups of anthocyanins (A), hydrolysable tannins (T), phenolic acids (Ac), and flavonoids $(\mathbf{F})$. The relative abundance as the percent of total anthocyanins, total hydrolysable tannins, total phenolic acids, and total flavonoids compared to TPC is given in Table 3 .

The total anthocyanin content was in range from $40.5 \mathrm{mg} / \mathrm{l}$ for Kisela (2017) to $465.2 \mathrm{mg} / \mathrm{l}$ for Hidzas (2016). The content of anthocyanins was notably higher in 2016 compared to 2017 for all varieties except for Zumnarija. The dominant anthocyanin in pomegranate was cyanidin-3-glucoside contributing 30 to $45 \%$ of the total anthocyanin content, but also there was cyanidin and delphinidin 3,5-diglucoside with 20 to $40 \%$ of the total anthocyanin content.

On the other hand, the total content of noncolored polyphenols was around 10 times lower in 2016 compared to the amount found in the samples from the same varieties in 2017.

Compounds T1-T4 (galloyl hexose, lagerstannin $\mathrm{C}$, pedunculagin I and punicalin) were detected only in the samples from 2017, whereas compound T7 (ellagic acid hexoside) only in the samples from 2016. The total content of hydrolys- able tannins in 2016 varied from $13 \mathrm{mg} / \mathrm{l}$ to 101 $\mathrm{mg} / \mathrm{l}$, which represents from 5-17\% of total the phenolic content, whereas in 2017 it was in range from $130.5 \mathrm{mg} / \mathrm{l}$ to $403.5 \mathrm{mg} / \mathrm{l}$, which represents $37-64 \%$ of the total phenolic content.

The group of phenolic acids contains hydroxycinnamic and hydroxybenzoic acid derivatives. The content of phenolic acid derivatives was in range of $13.19 \mathrm{mg} / \mathrm{l}$ to $77.3 \mathrm{mg} / \mathrm{l}$. Hydroxybenzoic acid derivatives were found only in the samples from 2016 but not in 2017. From the hydroxycinnamic acid derivatives, caffeoyl and feruloylquinic acid derivatives were dominant in both years, whereas caffeic acid contributed $20-40 \%$ to the total phenolic acid content but only in 2017, because it was not detected in 2016.

From the class of flavonoids, gallocatehin was found in 2017, whereas kaempferol hexoside in 2016. The content of quercetin in both years was similar and contributed 24 to $65 \%$ to the total flavonoid content.

The total phenolic content (in $\mathrm{mg} / \mathrm{l}$ ), calculated as a sum of the content of the individual compounds, was in the range from $148.6 \mathrm{mg} / \mathrm{l}$ for Limfonka 2016 to $786.4 \mathrm{mg} / \mathrm{l}$ for Zumnarija 2017. In general, TPCs were higher in 2017 than in 2016. Anthocyanins were the dominant group in 2016 year, and their contribution to TPC was between 75 and $80 \%$, followed by hydrolysable tannins (5$15 \%$ of TPC), phenolic acids (5-24\% of TPC), and flavonoids (1-3\%).

In contrast, in 2017 hydrolysable tannins were the dominant group, and they contributed with $37-65 \%$ of the TPC, followed by anthocyanins (10-30\% of TPC), flavonoids (10-20\%) and phenolic acids (3-15\%).

Despite the great number of studies, comparison of the phenolic content with literature data is still aggravated due to the following: a) different analytical methodologies that measure individual or classes of polyphenolic compounds, and b) the variability of the polyphenol composition depending on many factors, including the cultivar, the growing region, the maturity stage, environmental conditions, processing steps and storage conditions. As our results demonstrate, differences are evident not only between different pomegranate varieties but also for the samples from the same variety collected in different years.

The polyphenolic contents in different types of juices also differ due to differing procedures for the preparation of juice and which part of the arils are present during the procedure. In our case, we prepared the juices only from the isolated arils around the seeds, and we did not use the peel, mesocarp, or seeds. 
T a ble 2

Phenolic compound concentration (mg/l) in pomegranate juice from eight Punica granatum cultivars analyzed in two seasons (2016, 2017)

\begin{tabular}{|c|c|c|c|c|c|c|c|c|c|c|c|c|c|c|c|c|c|}
\hline $\begin{array}{c}\text { Peak } \\
\text { no. }\end{array}$ & Compound/Sample & $\mathbf{Z 1 6}^{\mathrm{a}}$ & Z17 & H16 & H17 & B16 & B17 & LC16 & L16 & L17 & R16 & R17 & KM16 & KM17 & V16 & V17 & KS17 \\
\hline & Anthocyanins & & & & & & & & & & & & & & & & \\
\hline A1 & del-3,5-diglc & $10.04^{\mathrm{b}}$ & 60.33 & 131.0 & 73.24 & 50.54 & 25.38 & 52.55 & 26.78 & 11.01 & 35.54 & 8.516 & 71.09 & 43.73 & 197.1 & 30.49 & 9.455 \\
\hline A2 & cya-3,5-diglc & 52.65 & 47.65 & 114.4 & 96.49 & 35.56 & 29.69 & 73.95 & 29.51 & 13.42 & 86.37 & 41.87 & 60.56 & 49.95 & 141.6 & 2.00 & 1.18 \\
\hline $\mathbf{A 3}$ & pel-3,5-diglc & 2.551 & 1.828 & 2.593 & 4.575 & 1.925 & 1.662 & 2.253 & nd & nd & 5.346 & 2.363 & 3.250 & 2.351 & 5.212 & 1.188 & 0.832 \\
\hline A4 & del-3-glc & 5.851 & 47.88 & 77.37 & 38.08 & 13.26 & 9.306 & 18.75 & 17.72 & 9.022 & 10.73 & 3.771 & 9.554 & 6.338 & 41.43 & 34.53 & 7.872 \\
\hline A5 & cya-3,5-pent-hex & nd & nd & nd & nd & nd & nd & nd & nd & nd & nd & nd & nd & nd & 2.185 & nd & nd \\
\hline A6 & cya-3-glu & 51.58 & 69.60 & 127.9 & 60.54 & 19.05 & 16.27 & 47.95 & 38.04 & 18.48 & 60.67 & 28.28 & 15.94 & 9.361 & 53.74 & 33.87 & 9.672 \\
\hline A7 & pel-3-glc & 6.071 & 4.071 & 7.884 & 3.662 & 1.878 & 1.686 & 2.463 & 2.871 & 1.149 & 9.754 & 2.763 & 2.277 & 0.630 & 3.754 & 1.551 & 1.531 \\
\hline \multirow[t]{4}{*}{ A8 } & cya-3-pent & nd & 1.128 & 4.005 & 1.641 & nd & nd & 1.356 & 0.565 & nd & nd & nd & nd & nd & 1.217 & 0.669 & nd \\
\hline & Total & 128.7 & 232.5 & 465.2 & 278.2 & 122.2 & 83.99 & 199.3 & 115.5 & 53.08 & 208.41 & 87.56 & 162.7 & 112.4 & 446.2 & 124.3 & 40.54 \\
\hline & $\begin{array}{l}\text { Hydro } \\
\text { tannin }\end{array}$ & & & & & & & & & & & & & & & & \\
\hline & $\underline{\text { Gallotannins }}$ & & & & & & & & & & & & & & & & \\
\hline \multirow[t]{2}{*}{ T1 } & galloyl hex & nd & 49.20 & nd & 46.25 & nd & 27.65 & nd & nd & 16.26 & nd & 13.80 & nd & 24.20 & nd & nd & 28.39 \\
\hline & Ellagitannins & & & & & & & & & & & & & & & & \\
\hline $\mathbf{T 2}$ & lagerstannin C & nd & 66.26 & nd & 134.9 & nd & 62.69 & nd & nd & 128.8 & nd & 78.67 & nd & 67.35 & nd & nd & 66.26 \\
\hline $\mathbf{T 3}$ & pedunculagin I & nd & 168.2 & nd & 74.51 & nd & 19.30 & nd & nd & nd & nd & nd & nd & nd & nd & nd & nd \\
\hline T4 & Punicalin & nd & 106.8 & nd & nd & nd & 202.4 & nd & nd & 168.2 & nd & 92.80 & nd & 153.5 & nd & 305.4 & 31.87 \\
\hline T5 & ellagic acid-pent & nd & 3.573 & 5.248 & 3.681 & 2.703 & 2.398 & 5.958 & nd & 2.995 & 4.218 & 3.198 & nd & 2.134 & 5.361 & nd & nd \\
\hline T6 & ellagic acid-rham & 15.64 & 3.432 & 37.59 & 3.588 & 3.889 & nd & 18.497 & 8.540 & nd & 17.81 & 3.972 & nd & nd & 19.65 & nd & nd \\
\hline T7 & ellagic acid-hex & 2.493 & nd & 17.45 & nd & 3.383 & nd & 16.403 & 3.756 & nd & 11.95 & nd & nd & nd & 11.56 & nd & nd \\
\hline \multirow[t]{4}{*}{ T8 } & ellagic acid & nd & 5.973 & 42.67 & 5.987 & 2.984 & 15.35 & 5.360 & 1.452 & 6.890 & 1.732 & 4.521 & 9.202 & 7.327 & 35.48 & 11.10 & 3.992 \\
\hline & Total & 18.13 & 403.5 & 101.0 & 268.9 & 12.96 & 329.8 & 46.218 & 13.75 & 323.1 & 35.72 & 197.0 & 9.202 & 254.5 & 72.05 & 316.5 & 130.5 \\
\hline & Phenol & & & & & & & & & & & & & & & & \\
\hline & $\begin{array}{l}\text { Hydr } \\
\text { ic aci }\end{array}$ & & & & & & & & & & & & & & & & \\
\hline Ac1 & caffeic hex & 5.109 & 2.197 & 0.914 & 25 & 235 & 453 & 2.140 & 04 & 24 & 4.531 & 80 & 7 & .578 & 1.900 & 040 & 2.898 \\
\hline Ac2 & $\begin{array}{l}\text { 5-O-caff-quinic } \\
\text { acid }\end{array}$ & 4.820 & 5.324 & 3.908 & 2.999 & 37.60 & 5.721 & 4.787 & 4.559 & 2.786 & 2.276 & 2.137 & 6.240 & 3.826 & 7.467 & 5.946 & 7.291 \\
\hline Ac3 & $\begin{array}{l}\text { feruloylquinic } \\
\text { acid }\end{array}$ & 0.328 & 11.22 & 0.395 & 19.95 & 0.349 & 2.547 & 0.379 & 0.123 & 23.97 & 0.321 & 9.475 & 0.168 & 9.939 & 0.505 & 0.869 & 14.08 \\
\hline Ac4 & feryllic acid hex & 2.778 & nd & 1.203 & nd & 3.009 & nd & 2.947 & 3.475 & nd & 3.747 & nd & 4.370 & nd & 3.070 & 110 & nd \\
\hline \multirow[t]{2}{*}{ Ac5 } & caffeic acid & nd & 11.22 & nd & 20.99 & nd & 2.473 & nd & nd & 23.52 & nd & 8.772 & nd & 9.504 & nd & nd & 15.28 \\
\hline & $\begin{array}{l}\text { Hydroxybenzoic } \\
\underline{\text { acids }}\end{array}$ & & & & & & & & & & & & & & & & \\
\hline Ac6 & gallic acid & nd & nd & nd & nd & nd & nd & nd & nd & nd & nd & nd & nd & nd & nd & 67.440 & nd \\
\hline \multirow[t]{4}{*}{ Ac7 } & vanillic acid hex & 2.602 & nd & 7.085 & nd & 2.982 & nd & 3.815 & 3.445 & nd & 4.366 & nd & 3.742 & nd & 5.099 & nd & nd \\
\hline & Total & 15.64 & 29.96 & 13.51 & 45.57 & 45.17 & 13.19 & 14.07 & 14.80 & 51.99 & 15.24 & 23.06 & 17.12 & 24.85 & 18.04 & 77.30 & 39.54 \\
\hline & Flavonoids & & & & & & & & & & & & & & & & \\
\hline & $\underline{\text { Flavan 3-ols }}$ & & & & & & & & & & & & & & & & \\
\hline \multirow[t]{2}{*}{ F1 } & gallocatehin & nd & 81.62 & nd & 71.17 & nd & 54.68 & nd & nd & 21.69 & nd & 46.42 & nd & 30.32 & nd & nd & 90.75 \\
\hline & $\underline{\text { Flavonols }}$ & & & & & & & & & & & & & & & & \\
\hline F2 & kaempferol hex & 1.432 & nd & 3.056 & 110 & 2.139 & nd & 5.573 & 2.101 & nd & nd & nd & 2.684 & nd & 4.538 & nd & nd \\
\hline \multirow[t]{3}{*}{ F3 } & quercetin & nd & 38.77 & 2.757 & 59.54 & 1.895 & 32.42 & 3.322 & 2.428 & 41.00 & 1.172 & 27.93 & 2.672 & 21.92 & 2.943 & 9.195 & 28.13 \\
\hline & Total & 1.432 & 120.39 & 5.813 & 130.7 & 4.034 & 87.10 & 8.895 & 4.529 & 62.70 & 1.172 & 74.35 & 5.356 & 52.24 & 7.481 & 9.195 & 118.9 \\
\hline & $\begin{array}{l}\text { Total phenolic } \\
\text { content }\end{array}$ & 163.9 & 786.4 & 585.5 & 723.4 & 184.4 & 514.1 & 268.5 & 148.6 & 490.9 & 260.5 & 382.0 & 194.4 & 444.0 & 543.8 & $\mathbf{5 2 7 . 3}$ & 329.5 \\
\hline
\end{tabular}

${ }^{a}$ Z-Zumnarija, H-Hidzas, B-Bejnarija, L-Limfonka, LC-Limfonka clone, R-Ropkavac, KM-Karamustafa, V-Valandovka,

KS-Kisela; 16 and 17, years of collections 2016 and 2017.

${ }^{b}$ Values represent the mean of three measurements (mean $\pm \mathrm{SD}$ ) 
T a ble 3

Relative abundance in percent of total anthocyanins, total hydrolysable tannins, total phenolic acids, and total flavonoids to TPC

\begin{tabular}{|l|c|c|c|c|c|c|c|c|c|c|c|c|c|c|c|c|}
\hline \hline \begin{tabular}{c} 
Compounds \\
\hline $\begin{array}{l}\text { Znthocya- } \\
\text { nins }\end{array}$
\end{tabular} & 78.5 & 29.6 & 79.5 & 38.5 & 66.3 & 16.3 & 74.2 & 77.7 & 10.8 & 80.0 & 22.9 & 83.7 & 25.3 & 82.1 & 23.6 & 12.3 \\
\hline $\begin{array}{c}\text { Hydrolysable } \\
\text { tannins }\end{array}$ & 11.1 & 51.3 & 17.2 & 37.2 & 7.0 & 64.2 & 17.2 & 9.3 & 65.8 & 13.7 & 51.6 & 4.7 & 57.3 & 13.3 & 60.0 & 39.6 \\
\hline $\begin{array}{c}\text { Phenolic } \\
\text { acids }\end{array}$ & 9.5 & 3.8 & 2.3 & 6.3 & 24.5 & 2.6 & 5.2 & 10.0 & 10.6 & 5.8 & 6.0 & 8.8 & 5.6 & 3.3 & 14.7 & 12.0 \\
\hline Flavonoids & 0.9 & 15.3 & 1.0 & 18.1 & 2.2 & 16.9 & 3.3 & 3.0 & 12.8 & 0.4 & 19.5 & 2.8 & 11.8 & 1.4 & 1.7 & 36.1 \\
\hline \hline
\end{tabular}

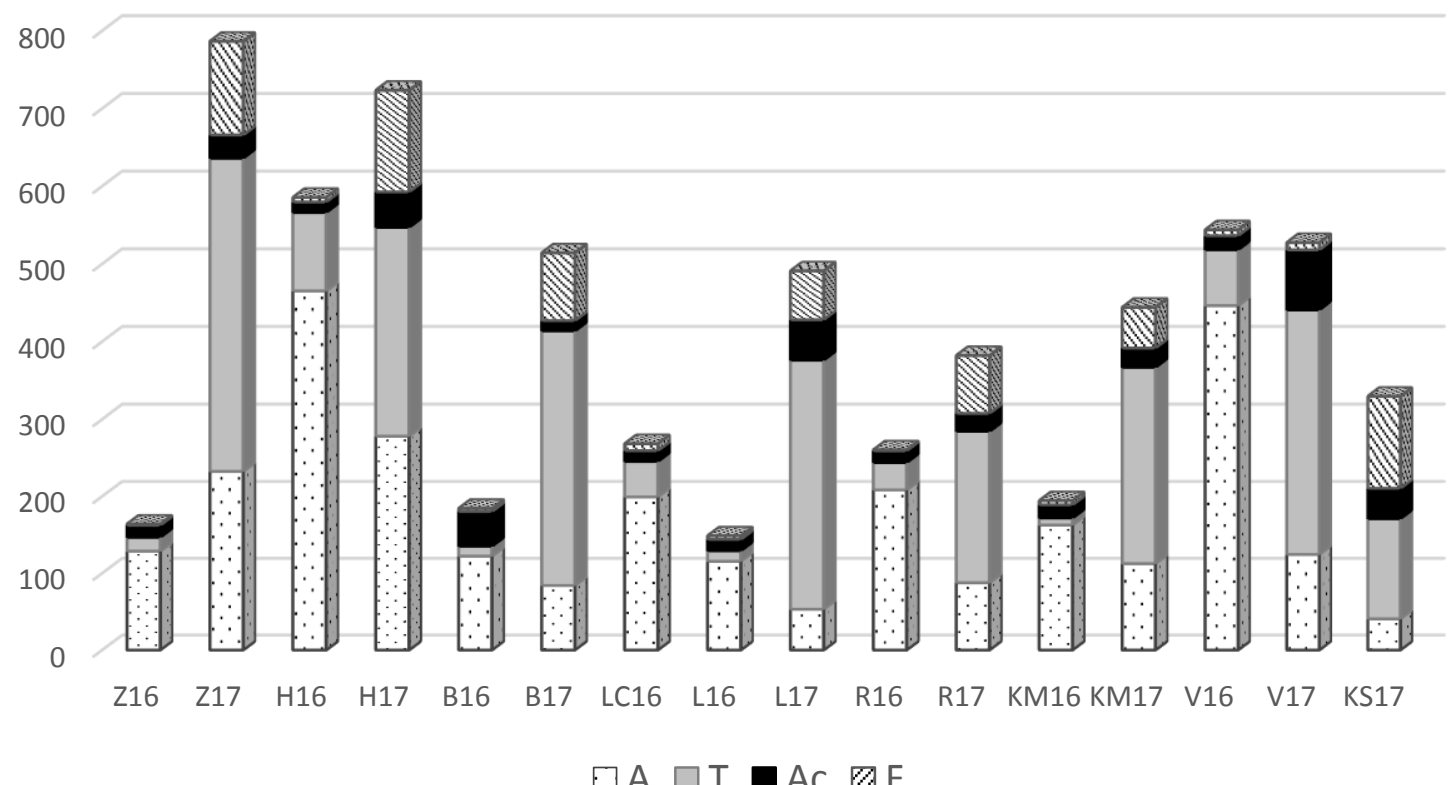

Fig. 4. Polyphenolic content (anthocyanins (A), hydrolysable tannins (T), phenolic acids (Ac) and flavonoids (F)) of pomegranate juice from eight Punica granatum cultivars collected and analyzed in two seasons $(2016,2017)$ (expressed in $\mathrm{mg} / \mathrm{l}$ )

The anthocyanins patterns and contents were very similar to those found in the literature. In the study of Gil et al. (2000) [17], the total anthocyanin content in different types of juice varied from $161.9 \mathrm{mg} / \mathrm{l}$ to $387.4 \mathrm{mg} / \mathrm{l}$. They concluded that when arils are frozen and stored prior to juice extraction, the anthocyanins are partly degraded and/or transformed into other products. The total anthocyanins content in 15 different Iranian pomegranate varieties (unprocessed juices, $\mathrm{mg} / \mathrm{l}$ ) [18] was in the range from $15.01 \mathrm{mg} / \mathrm{l}$ to $252.22 \mathrm{mg} / \mathrm{l}$. Fischer et al. (2011) [8] prepared different types of juice and they found differences in the anthocyanin content. The juice prepared only from isolated arils which were coating the seeds had the highest anthocyanin con- tent $(557.7 \mathrm{mg} / \mathrm{l})$ compared to the juice prepared from not separated fruits $(198.3 \mathrm{mg} / \mathrm{l})$.

The content of hydrolysable tannins in our study was lower compared to those found in the literature. In the results of Gil et al. (2000) [17], hydrolysable tannins were in range from 640.3 to $2699.4 \mathrm{mg} / \mathrm{l}$, whereas in the study of Fischer et al. (2011) [8] they were in the range from 93.2 to $2074.4 \mathrm{mg} / \mathrm{l}$. The total content of hydrolysable tannins is also in correlation with the procedure used for juice preparation, because it is known that the content of hydrolysable tannins is higher in the peel and mesocarp.

From the literature, it is also evident that when the total anthocyanin content was higher, the total content of hydrolysable tannins was lower. 
The content of the other detected compounds was minor and comparable to those found in the literature [19]. The content of hydroxycinnamic acids was in the range from 6.42 $\mathrm{mg} / \mathrm{l}$ to $52.0 \mathrm{mg} / \mathrm{l}$. Compounds Ac1-Ac3 were found in all analyzed samples, whereas compound Ac4 was present only in the samples of 2016 and compound Ac5 in the samples collected in 2017. Compound Ac6 was found only in one sample (V17), whereas compound Ac7 was in all samples collected in 2016.

Gallocatehin was not detected in the samples collected in 2016, and its content in the samples collected in 2017 ranged from $21.69 \mathrm{mg} / \mathrm{l}$ to $90.75 \mathrm{mg} / \mathrm{l}$.

Kaemferol hexoside was detected in the samples from 2016, with the content from 1.432 $\mathrm{mg} / \mathrm{l}$ to $5.573 \mathrm{mg} / \mathrm{l}$, whereas quercetin was detected in all analyzed samples (except Z16) and its content was lower in the samples collected in 2016 (1.172-3.322 mg/l) compared to those in the samples collected in $2017(9.195-59.4 \mathrm{mg} / \mathrm{l})$.

From our results, but also from literature data, we can conclude that pomegranate samples collected from Macedonia present a very rich source of polyphenolic compounds, but the polyphenol composition variability (both pattern and content) depends considerably on many factors such as the cultivar, the maturity stage, the growing region, environmental conditions, processing steps and storage conditions.

\section{REFERENCES}

[1] H. Boeing, A. Bechthold, A. Bub, S. Ellinger, D. Haller, A. Kroke, E. Leschik-Bonnet, M. J. Müller, H. Oberritter, M. Schulze, P. Stehle, B. Watzl, Critical review: vegetables and fruit in the prevention of chronic diseases, Eur. J. Nutr., 51, 637-663 (2012).

DOI: $10.1007 / \mathrm{s} 00394-012-0380-\mathrm{y}$.

[2] C. G. Fraga, K. D. Croft, D. O. Kennedye, F. A. TomásBarberán, The effects of polyphenols and other bioactives on human health, Food Funct. (2019). DOI: $10.1039 / \mathrm{c} 8$ fo01997e

[3] C. Manach, A. Scalbert, C. Morand, C. Rémésy, L. Jiménez, Polyphenols: food sources and bioavailability, Am. J. Clin. Nutr., 79, 727-747 (2004). DOI: https://doi.org/10.1093/ajen/79.5.727.

[4] A. R. Tapas, D. M. Sakarkar, R. B. Kakde, Flavonoids as nutraceuticals: A review, Trop. J. Pharm. Res., 7, 1089-1099, (2008).

DOI: http://dx.doi.org/10.4314/tjpr.v7i3.14693.

[5] D. Rymon, Mapping features of the global pomegranate market, Acta Hortic., 890, 599-602 (2011). DOI: $10.17660 /$ ActaHortic.2011.890.84.
[6] M. Viuda-Martos, J. Fernández-López, J. A. PérezÁlvarez, Pomegranate and its many functional components as related to human health: A review, Compr. Rev. Food Sci. Food Saf., 9, 635-654 (2010). DOI: https://doi.org/10.1111/j.1541-4337.2010.00131.x.

[7] D. A. Kruger, Composition of pomegranate juice, $J$. AOAC Int., 95, 163-168 (2012).

[8] U. A. Fischer, R. Carle, D. R. Kammerer, Identification and quantification of phenolic compounds from pomegranate (Punica granatum L.) peel, mesocarp, aril and differently produced juices by HPLC-DAD-ESI/MSn, Food Chem., 127, 807-821 (2011). DOI: https://doi.org/10.1016/j.foodchem.2010.12.156.

[9] F. Bonzanini, R. Bruni, G. Palla, N. Serlataite, A. Caligiani, Identification and distribution of lignans in Punica granatum L. fruit endocarp, pulp, seeds, wood knots and commercial juices by GC-MS, Food Chem., 117, 745-749 (2009). DOI: 10.1016/j.foodchem.2009.04.057.

[10] D. Del Rio, A. Rodriguez-Mateos, J. P. E. Spencer, M. Tognolini, G. Borges, C. Crozier, Dietary (Poly)phenolics in human health: structures, bioavailability and evidence of protective effects against chronic diseases, Antioxid. Redox. Signal., 18, 1818-1892 (2013). DOI: 10.1089/ars.2012.4581.

[11] S. H. Mirdehghan, M. Rahemi, Seasonal changes of mineral nutrients and phenolics in pomegranate (Punica granatum L.) fruit, J. Sci. Hort., 111, 120-127 (2007). DOI: https://doi.org/10.1016/j.scienta.2006.10.001.

[12] F. A. Tomás-Barberán, M. I. Gil, P. Cremin, A. L. Waterhouse, B. Hess-Pierce, A. A. Kader, HPLC-DADESIMS Analysis of Phenolic Compounds in Nectarines, Peaches, and Plums, J. Agric. Food Chem., 49, 4748-4760, (2001). DOI: 10.1021/jf0104681.

[13] E. Sentandreu, M. Cerdá n-Calero, J. M. Sendra, Phenolic profile characterization of pomegranate (Punica granatum) juice by high-performance liquid chromatography with diode array detection coupled to an electrospray ion trap mass analyzer, J. Food. Compos. Anal., 30, 32-40 (2013). DOI: https://doi.org/10.1016/j.jfca.2013.01.003.

[14] L. Calani, D. Beghè, P. Mena, D. Del Rio, R. Bruni, A. Fabbri, C. Dall'Asta, G. Galaverna, Ultra-HPLC-MSn (Poly)phenolic Profiling and Chemometric Analysis of Juices from Ancient Punica granatum L. Cultivars: A Nontargeted Approach, J Agric Food Chem., 61, 56005609 (2013). DOI: 10.1021/jf400387c.

[15] T. Okuda, T. Yoshida, M. Ashida, K. Yazaki, Tannins of Casuarina and Stachyurus species. Part 1. Structures of pendunculagin, casuarictin, strictinin, casuarinin, casuariin, and stachyurin, J. Chem. Soc., Perkin Trans., 1, 1765-1772 (1983). DOI: 10.1039/p19830001765.

[16] M. Seikel, W. Hillis, Hydrolysable tannins of Eucalyptus delegatensis wood, Phytochemistry, 9, 1115-1128 (1970). DOI: https://doi.org/10.1016/S0031-9422(00)85235-8.

[17] M. I. Gil, F. A. Tomás-Barberán, B. Hess-Pierce, D. M. Holcroft, A. A. Kader, Antioxidant Activity of Pomegranate Juice and Its Relationship with Phenolic Composition and Processing, J. Agric. Food Chem., 48, 4581-4589 (2000). DOI: 10.1021/jf000404a. 
[18] H. Alighourchi, M. Barzegar, S. Abbasi, Anthocyanins characterization of 15 Iranian pomegranate (Punica granatum $\mathrm{L}$.) varieties and their variation after cold storage and pasteurization, Eur Food Res Technol., 227, 881-887 (2008). DOI: 10.1007/s00217-007-0799-1.
[19] I. Hmid, D. Elothmani, H. Hanine, A. Oukabli, E. Mehinagic, Comparative study of phenolic compounds and their antioxidant attributes of eighteen pomegranate (Punica granatum L.) cultivars grown in Morocco, Arab. J. Chem. (2013).

DOI: http://dx.doi.org/10.1016/j.arabjc.2013.10.011. 